\title{
Kinetic study of oil extraction from olive foot cake
}

\author{
By S. Meziane, H. Kadi ${ }^{1 *}$ and O. Lamrous ${ }^{2}$ \\ ${ }^{1}$ Laboratoire de Chimie Appliquée et de Génie Chimique, Faculté des Sciences, \\ Université Mouloud Mammeri, 15000 Tizi-Ouzou, Algérie. \\ ${ }^{2}$ Laboratoire de Physique et de Chimie Quantique, Faculté des Sciences, \\ Université Mouloud Mammeri, 15000 Tizi-Ouzou, Algérie. \\ *Corresponding author: H.Kadi, B.P 70, Poste Annane, 15010 TIZI-OUZOU, ALGERIA. \\ e-mail: hocinekadi@yahoo.fr
}

\section{RESUMEN}

\section{Estudio cinético de la extracción de aceite de orujo}

La cinética de extracción de aceite de orujo puede ser explicada por un modelo basado en dos etapas. La primera etapa corresponde a un simple lavado del aceite de la superficie de las partículas. En la segunda etapa, la extracción esta controlada por dos mecanismos: difusión lenta desde las células rotas y difusión muy lenta desde las células intactas.

Los coeficientes cinéticas de este modelo matemático se calculan usando los resultados experimentales obtenidos con hexano y alcohol etílico comercial para diferentes tamaños de partícula.

PALABRAS-CLAVE: Aceite de orujo - Difusión - Extracción - Solvente.

\section{SUMMARY}

\section{Kinetic study of oil extraction from olive foot cake}

The kinetics of oil extraction from olive foot cake can be explained by a model based on two stages. The first step corresponds to a simple washing of the oil from the particle surface. In the second step, the extraction is controlled by two mechanisms: slow diffusion from broken cells and very slow diffusion from intact cells.

The kinetic coefficients of this mathematical model are calculated using the experimental results obtained from hexane and commercial ethyl alcohol for different particle sizes. Solvent

KEY-WORDS: Diffusion - Extraction - Olive foot cake oil -

\section{INTRODUCTION}

The oil of olive foot cake is of important economic interest. For this reason, much work has been done to improve the yield of this oil recovered by solvent (Cana Munoz et al., 1976; Kmieciak et al., 1991; Kadi and Fellag, 2001).

Numerous theories have been proposed to explain the mechanism of oil recovery by solvent from oil cakes and oilseeds. So, the effect of the nature of the solvent (Hensarling and Jack, 1983; Kmieciak et al., 1991), particle size (Othmer and Agarwal, 1955; Becker and McKee, 1978; Patricelli et al., 1979; So and Macdonald, 1986; Wiese and Snyder, 1987; Schneeberger et al., 1988), temperature (Becker and McKee, 1978; Patricelli et al., 1979; So and Macdonald, 1986; Schneeberger et al., 1988) and moisture (Cana Munoz et al., 1976, Patricelli et al., 1979) on the yield has been demonstrated. However, it is worth mentioning that the molecular diffusion does not correspond to experimental results (Othmer and Agarwal, 1955; Patricelli et al., 1979; So and Macdonald, 1986). On the contrary, Schneeberger et al. (1988) showed that the kinetics of oil extraction by solvents in hazelnut cells which are not deteriorated is controlled by diffusion kinetics. It seems that the best mechanism adapted to oil cakes is described in two stages. The first is relative to the oil being at the grain surface and recovered by a simple washing and the second stage corresponds to a diffusion process which is able to take place in one or two phases.

Although many studies have been developed on oil extraction from olive foot cake, not one of them is based on the equations of mass transfer. Our objective in this paper is to present a study of the kinetics of solvent extraction of this residual oil in an agitated isotherm reactor working in a discontinuous regime.

\section{MATERIAL AND METHODS}

The olive foot cake used was taken from a continuous centrifugation system. Its initial moisture content was $48.0 \%$ which was reduced by drying to an interval ranging between 5 and $10 \%$. The oil content of the sample was $6.50 \%$. It was determined by an exhaustive extraction using hexane in a soxhlet apparatus.

The sample was ground using an electric cereal mill with millstones "S.A.M.A.P" type F100. Average 
particle sizes obtained were: $1.69 ; 1.03$ and 0.69 $\mathrm{mm}$. The results are summarized in table 1 .

The batch extraction was carried out in a cylindrical reactor of $600 \mathrm{ml}\left(\varnothing_{\mathrm{r}}=85 \mathrm{~mm}\right.$; $\mathrm{h}=106$ $\mathrm{mm}$ ) supplied with a mechanical agitator. The agitation turbine in stainless steel was equipped with 4 blades tilted to $45^{\circ}\left(\varnothing_{\mathrm{b}}=51 \mathrm{~mm}\right)$. The solidliquid separation was performed under reduced pressure. The miscella was distilled by means of a rotary evaporator.

The extractions have been carried out under the following conditions:

- kinetic study: solvent-to-solid ratio, $\frac{L}{S}=4$; extraction temperature, $\mathrm{T}=25^{\circ} \mathrm{C}$; agitation speed, $V_{\mathrm{a}}=800 \mathrm{rpm}$; extraction time, t: from 0 to $60 \mathrm{~min}$

- study at equilibrium: $\frac{\mathrm{L}}{\mathrm{S}}=4 ; \mathrm{T}=25^{\circ} \mathrm{C} ; \mathrm{t}=150$

The weight of the cake submitted to extraction was always $50 \mathrm{~g}$. Each yield value calculated was the average of three tests for the kinetic study and five tests for the equilibrium study.

The HPLC grade hexane and ethyl alcohol $96.0 \%$ $(\mathrm{v} / \mathrm{v})$ purity were used in all oil extraction experiments. Their average densities were 0.664 and 0.806 , respectively. These solvents are Prolabo products.

\section{MATHEMATICAL MODEL}

The mechanism of oil extraction from oleaginous seeds assumes that the oil transfer from the solid phase to the liquid phase is carried out in two simultaneous processes: a predominant washing process and a diffusion process.

Patricelli et al. (1979), working on uninterrupted oil extraction from sunflower seeds, proposed a model where the concentration $\mathrm{C}_{t}$ at any time is given by the equation:

$$
C_{t}=C_{e}^{w}\left(1-\exp \left(-k_{w} t\right)\right)+C_{e}^{d}\left(1-\exp \left(-k_{d} t\right)\right)
$$

where,

$\mathrm{C}_{\mathrm{e}}^{\mathrm{w}}$ : oil concentration to equilibrium in the solvent due to the washing step

$\mathrm{C}_{\mathrm{e}}^{\mathrm{d}}$ : oil concentration at equilibrium in the solvent due to the diffusion step

$\mathrm{k}_{\mathrm{w}}$ : mass transfer coefficient for the washing step

$\mathrm{k}_{\mathrm{d}}$ : mass transfer coefficient for the diffusion step
The final oil concentration in miscella at time equal to infinity:

$$
\mathrm{C}_{\mathrm{e}}=\mathrm{C}_{\mathrm{e}}^{\mathrm{w}}+\mathrm{C}_{\mathrm{e}}^{\mathrm{d}}
$$

The model applied by So and Macdonald (1986) for the oil extraction from canola (rapeseed) derives from the preceding model. It considers the possibility of two distinct steps of diffusion inside the seed.

- slow, unhindered diffusion of oil held in the ruptured cells of the seed

- a very slow, hindered diffusion of oil held within unruptured cells of the seed.

The transfer equation is then written:

$$
\begin{aligned}
C_{t}=C_{e}^{w}(1- & \left.\exp \left(-k_{w} t\right)\right)+C_{e}^{d 1}\left(1-\exp \left(-k_{d 1} t\right)\right)+ \\
& +C_{e}^{d 2}\left(1-\exp \left(-k_{d 2} t\right)\right)
\end{aligned}
$$

at equilibrium

$$
C_{e}=C_{e}^{w}+C_{e}^{d 1}+C_{e}^{d 2}
$$

The value $\mathrm{C}_{\mathrm{e}}$ corresponds to the concentration at equilibrium. It has been determined experimentally.

In this study, we have then tried to determine the applicability of these two mathematical models to the oil extraction from olive foot cake by studying the extraction yield according to time for different particle sizes and solvents. This yield $\rho_{t}$, calculated on a dry basis, can be expressed by the equation:

$$
\begin{array}{ll}
\text { Model I: } & \rho_{\mathrm{t}}=\rho_{\mathrm{t}}-\rho_{\mathrm{e}}^{\mathrm{w}} \exp \left(-\mathrm{k}_{\mathrm{w}} \mathrm{t}\right)-\rho_{\mathrm{e}}^{\mathrm{d}} \exp \left(-\mathrm{k}_{\mathrm{d}} \mathrm{t}\right) \\
\text { with } & \rho_{\mathrm{e}}=\rho_{\mathrm{e}}^{\mathrm{w}}+\rho_{\mathrm{e}}^{\mathrm{d}} \\
\text { Model II: } & \rho_{\mathrm{t}}=\rho_{\mathrm{e}}-\rho_{\mathrm{e}}^{\mathrm{w}} \exp \left(-\mathrm{k}_{\mathrm{w}} \mathrm{t}\right)-\rho_{\mathrm{e}}^{\mathrm{d} 1} \exp \left(-\mathrm{k}_{\mathrm{d} 1} \mathrm{t}\right) \\
& -\rho_{\mathrm{e}}^{\mathrm{d} 2} \exp ^{\mathrm{w}}\left(-\mathrm{k}_{\mathrm{d} 2} \mathrm{t}\right) \\
\text { with } & \rho_{\mathrm{e}}=\rho_{\mathrm{e}}^{\mathrm{w}}+\rho_{\mathrm{e}}^{\mathrm{d} 1}+\rho_{\mathrm{e}}^{\mathrm{d} 2}
\end{array}
$$

where,

$\rho_{\mathrm{e}}$ : oil yield of the extraction to equilibrium

$\rho_{e}^{\mathrm{w}}$ : oil yield to equilibrium for the washing step

$\rho_{\mathrm{e}}^{\mathrm{d}}$ : oil yield to equilibrium for the diffusion step

1 and 2: relative indexes at the first and the second diffusion

The oil yields at equilibrium according to the particle size and nature of the solvent $\left(\rho_{\mathrm{e}}\right)$ have been determined experimentally. The kinetic coefficients $\mathrm{k}_{\mathrm{w}} \mathrm{k}_{\mathrm{d} 1}$ and $\mathrm{k}_{\mathrm{d} 2}$ as well as the oil yields at equilibrium $\rho_{\mathrm{e}}^{\mathrm{w}}, \rho_{\mathrm{e}}^{\mathrm{d} 1}$ and $\rho_{\mathrm{e}}^{\mathrm{d} 2}$ have been calculated numerically with a non-linear least squares fitting method using program "Origin 7.0".

Table 1

Characteristics of samples and yields of extraction at equilibrium

\begin{tabular}{c|c|c|c|c}
\hline \multicolumn{2}{c|}{ Average diameter of sample (mm) } & 1.69 & 1.03 & 0.64 \\
\hline \multicolumn{2}{c}{ Moisture (\%) } & 5.9 & 5.85 & 5.48 \\
\hline \multirow{2}{*}{$\begin{array}{c}\text { Oil content } \\
\text { at equilibrium (\%)* }\end{array}$} & Hexane & & 5.82 \\
\cline { 2 - 5 } & Ethyl alcohol $96.0 \%$ & \multicolumn{3}{|c}{5.22} \\
\hline
\end{tabular}

${ }^{*}$ calculated on dry basis 


\section{RESULTS AND DISCUSSION}

\subsection{Study at equilibrium}

Table 1 presents the oil yield at equilibrium according to granulometry and the nature of the solvent. These results obtained after a contact time of 150 hours show that the yield is independent of the particle size. This conclusion is in agreement with that of So and Macdonald (1986) who studied the oil extraction from canola (rapeseed). These authors showed that the equilibrium is reached after about 3 days for $0.06 \mathrm{~mm}$ thickness and after 6 days for $0.76 \mathrm{~mm}$ thickness.

As shown in Table 1, hexane appears to be the solvent that gives the best yield. It extracts approximately $10.3 \%$ more fat matter than ethyl alcohol $96.0 \%$.

\subsection{Kinetic Study}

The data from our experiments are first fitted with mathematical model I based on a washing stage and a single diffusion. Figures $1 \mathrm{a}$ and $1 \mathrm{~b}$ show the extraction graphs with ethyl alcohol $96.0 \%$ and hexane according to the contact time and for different particle sizes. A first visual analysis especially indicates a good fit for the low

granulometries. Model II, which implies two diffusion stages, gives better results as shown in figures $2 a$ and $2 b$.

These curves also show that the oil yield increases very quickly with time at the beginning of the extraction. This rapid increase could be explained by the fact that this first stage which in general lasts 3 to 11 min for model I and one halfminute to $6 \mathrm{~min}$ for model II corresponds to the washing process from the grain surface.

The second stage is characterized by a yield which increases less and less rapidly. Then, the extraction is only assured by diffusion which is an increasingly slow process.

Tables 2 and 3 give the calculated values of the kinetic coefficients of the washing and diffusion stages for different particle sizes and different

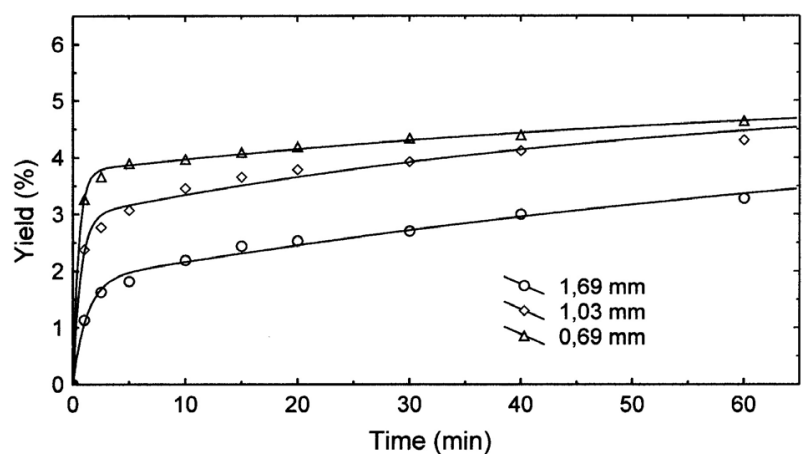

Figure 1a

Fit of model I to the extraction with ethyl alcohol $96.0 \%$ showing the effect of particle size

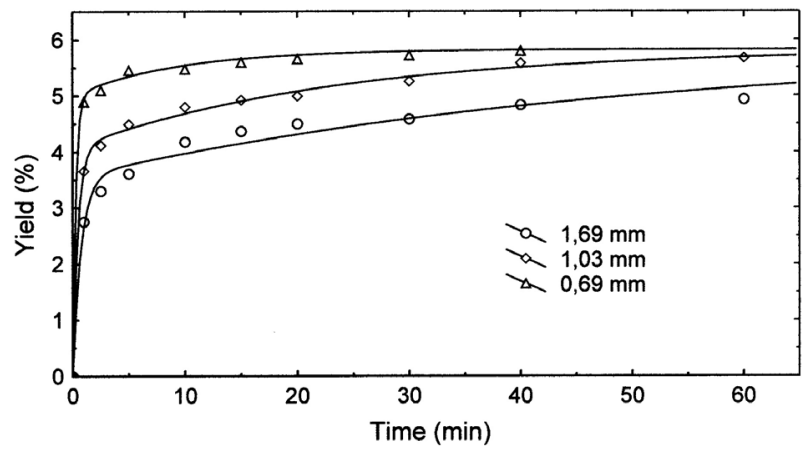

Figure $1 \mathrm{~b}$

Fit of model I to the extraction with hexane showing the effect of particle size

solvents. One can observe that extraction by washing is more effective than that resulting from diffusion. The determination coefficients $r^{2}$ indicate a good fit for model I $\left(0.987 \leq r^{2} \leq 1.000\right)$ and a very good fit for model II $\left(0.991 \leq r^{2} \leq 1.000\right)$. In the case of model I, the kinetic coefficients of washing are 33 to 126 times greater than for the diffusion stage. For model II, the washing coefficients are 9 to 151 times greater than those of the first diffusion and those for diffusion 1 are 7 to 47 times greater than for diffusion 2. It should be noted that all the coefficients of washing and diffusion of model II are higher than those of model I, for a given solvent and granulometry.

Table 2

Coefficients of mass transfer and yields at equilibrium of model I

\begin{tabular}{|c|c|c|c|c|c|c|}
\hline \multicolumn{7}{|c|}{ MODEL I } \\
\hline \multirow{2}{*}{ Solvent } & \multirow{2}{*}{$\begin{array}{c}\text { Average } \\
\text { diameter } \\
(\mathrm{mm})\end{array}$} & \multicolumn{2}{|c|}{$\begin{array}{c}\text { Coefficients of } \\
\text { mass transfer }\left(\mathrm{min}^{-1}\right)\end{array}$} & \multicolumn{2}{|c|}{$\begin{array}{c}\text { Yields at } \\
\text { equilibrium (\%) }\end{array}$} & \multirow{2}{*}{$\begin{array}{c}\begin{array}{c}\text { Coefficients of } \\
\text { determination }\end{array} \\
r^{2}\end{array}$} \\
\hline & & $\mathbf{k}_{\mathrm{w}}$ & $\mathbf{k}_{\mathrm{d}}$ & $\rho_{\mathrm{e}}^{\mathrm{w}}$ & $\rho_{e}^{d}$ & \\
\hline Ethyl & 1.69 & 0.81 & 0.0100 & 1.84 & 3.38 & 0.9923 \\
\hline alcohol & 1.03 & 1.46 & 0.0185 & 2.96 & 2.26 & 0.9940 \\
\hline \multirow[t]{2}{*}{$96.0 \%$} & 0.69 & 1.97 & 0.0156 & 3.76 & 1.46 & 0.9984 \\
\hline & 1.69 & 1.23 & 0.0191 & 3.66 & 2.16 & 0.9887 \\
\hline \multirow[t]{2}{*}{ Hexane } & 1.03 & 2.08 & 0.0425 & 4.08 & 1.74 & 0.9976 \\
\hline & 0.69 & 3.57 & 0.1086 & 5.00 & 0.82 & 0.9996 \\
\hline
\end{tabular}


Table 3

Coefficients of mass transfer and yields at equilibrium of model II

\begin{tabular}{lcccccccc}
\hline \multicolumn{7}{c}{ MODEL II } \\
\hline Solvent & $\begin{array}{c}\text { Average } \\
\text { diameter } \\
(\mathbf{m m})\end{array}$ & \multicolumn{3}{c}{$\begin{array}{c}\text { Coefficients of } \\
\text { mass transfer }\left(\mathbf{m i n}^{-1}\right)\end{array}$} & \multicolumn{3}{c}{$\begin{array}{c}\text { Yields at } \\
\text { equilibrium (\%) }\end{array}$} & $\begin{array}{c}\text { Coefficients of } \\
\text { determination }\end{array}$ \\
\cline { 3 - 10 } & & $\mathbf{k}_{\mathrm{w}}$ & $\mathbf{k}_{\mathrm{d} 1}$ & $\mathbf{k}_{\mathrm{d} 2}$ & $\rho_{\mathrm{e}}^{\mathrm{w}}$ & $\rho_{\mathrm{e}}^{\mathrm{d} 1}$ & $\rho_{\mathrm{e}}^{\mathrm{d} 2}$ & $\mathbf{r}^{2}$ \\
\hline Ethyl & 1.69 & 1.48 & 0.158 & 0.0078 & 1.30 & 0.83 & 3.09 & 0.9986 \\
alcohol & 1.03 & 2.86 & 0.174 & 0.0109 & 2.31 & 1.17 & 1.74 & 0.9997 \\
$96.0 \%$ & 0.69 & 46.82 & 0.695 & 0.0143 & 2.67 & 1.16 & 1.39 & 0.9998 \\
\hline \multirow{3}{*}{ Hexane } & 1.69 & 3.20 & 0.270 & 0.0132 & 2.44 & 1.64 & 1.74 & 0.9960 \\
& 1.03 & 47.62 & 0.651 & 0.0367 & 2.89 & 1.38 & 1.55 & 0.9987 \\
& 0.69 & 60.98 & 0.403 & 0.0607 & 4.66 & 0.61 & 0.55 & 0.9998 \\
\hline
\end{tabular}

Figures $1 \mathrm{a}, 1 \mathrm{~b}, 2 \mathrm{a}$ and $2 \mathrm{~b}$ also indicate that the particle size has a great influence on the extraction; the yield increases when the particle size decreases. This fact is confirmed by the general increase in all kinetic coefficients given in tables 2 and 3 .

The results presented in these tables show that the nature of the solvent has an effect on transfer coefficients. In the case of both models, hexane gives the best transfer coefficients in all the steps of washing and diffusion for the same particle size. This is confirmed by figures $3 a, 3 b$ and $3 c$ represented by model II which show that, for a given granulometry, hexane always extracts more oil than ethyl alcohol $96.0 \%$.

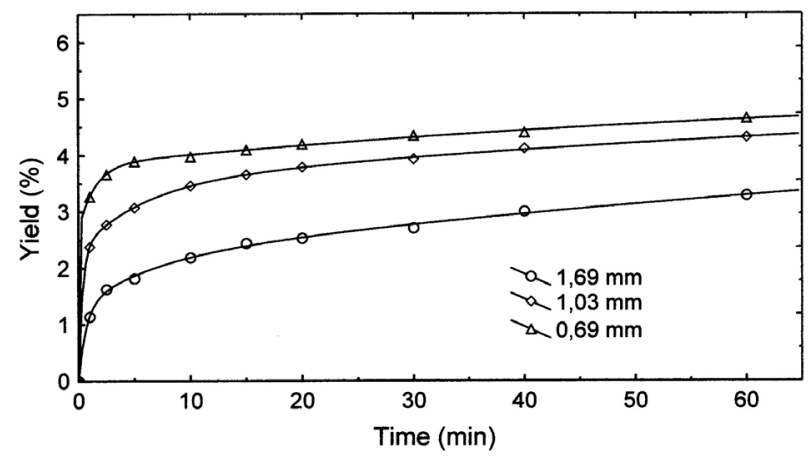

Figure 2a

Fit of model II to the extraction with ethyl alcohol $96.0 \%$ showing the effect of particle size

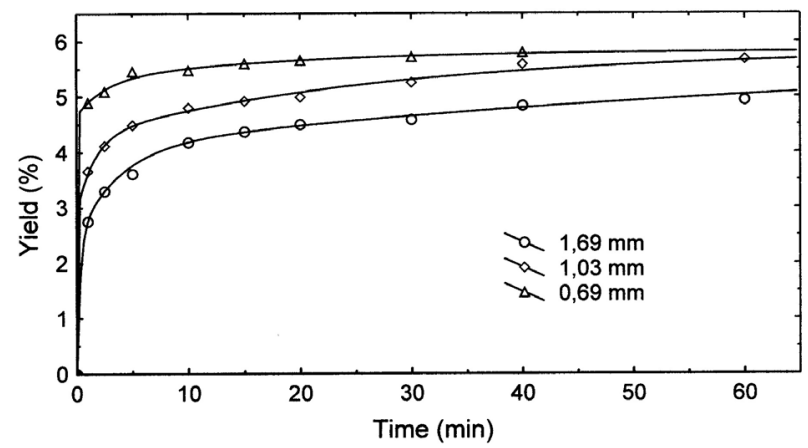

Figure $2 b$

Fit of model II to the extraction with hexane showing the effect of particle size

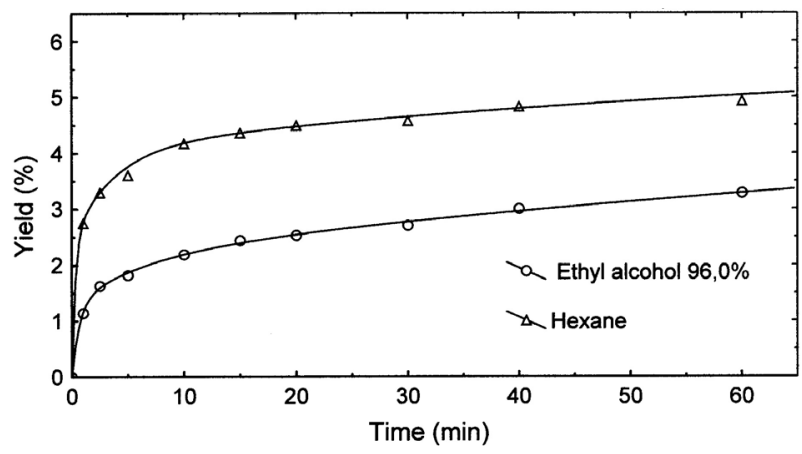

Figure $3 a$

Fit of model II to extraction with $1.69 \mathrm{~mm}$ diameter showing the effect of solvent nature

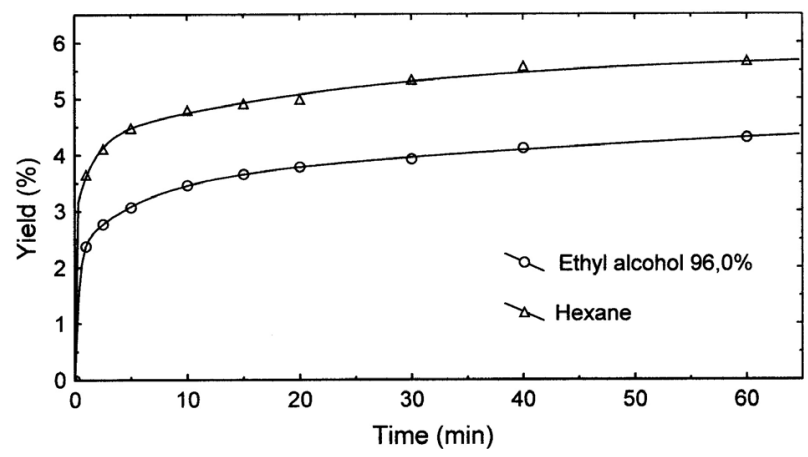

Figure $3 b$

Fit of model II to extraction with $1.03 \mathrm{~mm}$ diameter showing the effect of solvent nature

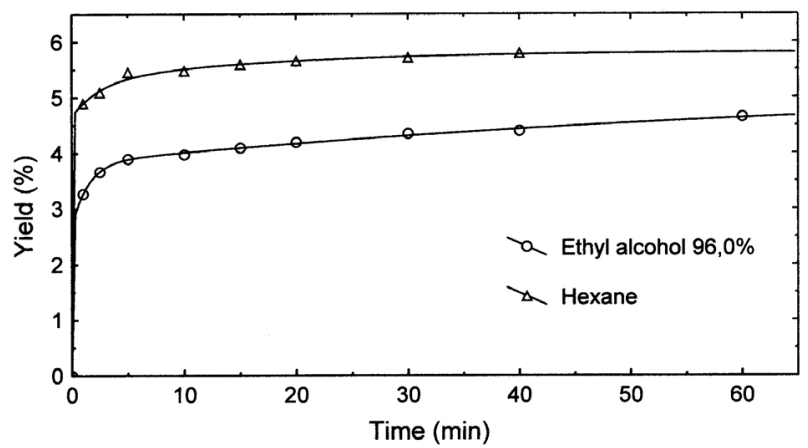

Figure 3c

Fit of model II to extraction with $0.69 \mathrm{~mm}$ diameter showing the effect of solvent nature 


\section{CONCLUSION}

The study of oil extraction at equilibrium showed that the yield after 150 hours of contact is independent of the particle size for a given solvent. It also appears that hexane is the solvent which extracts the most fat matter.

The results produced by model I and especially by model II are in agreement with the experimental results. However, model I seems more adequate because it is easier to use: it requires less parameters that model II.

In both models, the predominant mechanism in the extraction process is the washing of oil from the particle surface. This washing which allows the recovery of a significant quantity of oil is finished in about 11 minutes for model $I$ and 6 minutes for model II. The extraction is then assured by the diffusion process only.

It is important to point out as well that the extraction is influenced by particle size and by the nature of the solvent. Hexane gives the highest kinetic coefficients in all cases. These coefficients increase in both models when the particle size decreases. We notice that the amount of extracted oil during the washing stage increases with the decrease of particle size. For extraction with hexane, the decrease in size from 1.69 to $0.69 \mathrm{~mm}$ leads to an increase in oil yield from 42.0 to $80.0 \%$. This variation is less significant (25.0 to $51.0 \%)$ in the case of ethyl alcohol.

Both models, while giving good results, do not describe the extraction process such as it occurs since they consider that the steps of washing and diffusion happen simultaneously. However, in reality, the diffusion process of oil in a solvent can only begin when the washing step is finished.

\section{NOMENCLATURE}

$\mathrm{C}_{\mathrm{t}}$ : oil concentration in the solvent at any time ( $\mathrm{g}$ oil / $100 \mathrm{~g}$ miscella)

$\mathrm{C}_{\mathrm{e}}$ : oil concentration to equilibrium after the extraction process has been completed ( $\mathrm{g}$ oil / 100 g miscella)

$\mathrm{C}_{\mathrm{e}}^{\mathrm{w}}$ : oil concentration to equilibrium in the solvent due to washing stage ( $\mathrm{g}$ oil / $100 \mathrm{~g}$ miscella)

$\mathrm{C}_{\mathrm{e}}^{\mathrm{d}}$ : oil concentration at equilibrium in the solvent due to diffusion step (g oil / $100 \mathrm{~g}$ miscella)

$\mathrm{h}$ : height of reactor $(\mathrm{mm})$

$\mathrm{k}_{\mathrm{d}}$ : coefficient of mass transfer for diffusion step $\left(\min ^{-1}\right)$ $\mathrm{k}_{\mathrm{w}}$ : coefficient of mass transfer for washing step $\left(\min ^{-1}\right)$

$\frac{\mathrm{L}}{\mathrm{S}}$ : solvent-to-solid ratio ( $\mathrm{ml}$ solvent / g solids)

$r^{2}$ : coefficient of determination

t: extraction time (min)

T: extraction temperature $\left({ }^{\circ} \mathrm{C}\right)$

$\mathrm{V}_{\mathrm{a}}$ : agitation speed (rpm)

$\rho_{\mathrm{t}}$ : oil yield of the extraction at any time ( $\mathrm{g}$ oil / $100 \mathrm{~g}$ solids)

$\rho_{\mathrm{e}}$ : oil yield of the extraction to equilibrium ( $\mathrm{g}$ oil / $100 \mathrm{~g}$ solids)

$\rho_{\mathrm{e}}^{\mathrm{w}}$ : oil yield to equilibrium for washing stage ( $\mathrm{g}$ oil / $100 \mathrm{~g}$ solids)

$\rho_{\mathrm{e}}^{\mathrm{d}}$ : oil yield to equilibrium for diffusion stage ( $\mathrm{g}$ oil / $100 \mathrm{~g}$ solids)

$\varnothing_{\mathrm{b}}$ : diameter of agitator blade $(\mathrm{mm})$

$\varnothing_{\mathrm{r}}$ : diameter of reactor $(\mathrm{mm})$

1 and 2: relative indexes after first and the second diffusions

\section{REFERENCES}

Becker W, McKee AG. 1978. Solvent extraction IV: the effect of temperature on extraction rate. J. Amer. Oil Chem. Soc. 55, 756-761.

Cana Munoz G, Hermida Bun JR, Ascanio Hidalgo E. 1976. Extraccion de orujos de aceituna. Influencia de factores que afectan al rendimiento en aceite. Grasas y Aceites 27 (5) 369-372.

Hensarling TP, Jack TJ. 1983. Solvent extraction of lipids from soybeans with acidic hexane. J. Amer. Oil Chem. Soc. 60 (3) 783-784.

Kadi H, Fellag H.2001. Modeling of oil extraction from olive foot cake using hexane. Grasas y Aceites 52 (6) 369-372.

Kmieciak S, Meziane S, Kadi H, Moussaoui R. 1991. Oil extraction from olive foot cake with acidic hexane. Grasas y Aceites 42 (1) 46-50.

Othmer DF, Agarwal JC. 1955. Extraction of soybeans. Chemical Engineering Progress 51 (8) 372-378.

Patricelli A, Assogna A, Casalaina A, Emmi E, Sodini G. 1979. Fattori che influenzano l'estrazione dei lipidi da semi decorticati di girasole. La Rivista Italiana Delle Sostanze Grasse 56, 136-142.

Schneeberger R, Villarroel M, Drapela N, Caire F, Castillo M. 1988. Cinética de extraccion de aceite de avellana. Grasas y Aceites 39 (3) 151-154.

So GC, Macdonald DG. 1986. Kinetics of oil extraction from Canola (Rapeseed). The Candian Journal Of Chemical Engineering 64, 80-86.

Wiese L, Snyder HE. 1987. Analysis of the oil extraction progress in soybeans: a new continuous procedure. J. Amer. Oil Chem. Soc. 64 (3) 402-406.

Recibido: Noviembre 2004 Aceptado: Octubre 2005 